\title{
Tissue engineering from Adam to the zygote: historical reflections
}

\begin{abstract}
Tissue engineering, long a matter of myth and dream throughout the history of medicine, is now a practical reality. A wide spectrum of biological materials are used in the field of urology to treat disease and to overcome human disabilities, including tissue grafts and organ transplantation. Laboratory-engineered bioproducts for the off-the-shelf replacement and reconstruction of tissue is now almost at hand. This article presents a glimpse into the past by highlighting a number of early pioneering works in the field of tissue transplantation and cell culture technologies.
\end{abstract}

Key words Tissue engineering - Transplantation · Cell culture $\cdot$ Urology $\cdot$ History of medicine

We can begin this review of the historical roots of tissue engineering with the following definitions:

- Engineering: (a) The science concerned with putting scientific knowledge to practical uses; (b) the planning designing, construction, etc. [1]

- Tissue: A collection of similar cells and the intercellular substances surrounding them. There are four basic tissues in the body: (a) epithelium; (b) the connective tissues, including blood, bone, and cartilage; (c) muscle tissue; and (d) nerve tissue [2].

The term "tissue engineering" was introduced to medicine in 1987, and a definition was agreed upon at the inaugural tissue engineering meeting at Lake Tahoe,

D. Schultheiss $(\bowtie) \cdot J$. Wefer $\cdot$ U. Jonas Department of Urology, Hannover Medical School, Carl-Neuberg-Strasse 1, 30625 Hannover, Germany e-mail: schultheiss.dirk@mh-hannover.de Tel.: + 49-511-5326673; Fax: +49-511-5323481

D. A. Bloom

Department of Pediatric Urology,

University of Michigan, Ann Arbor, Mich., USA
California, 1 year later [56]: "Tissue engineering is the application of the principles and methods of engineering and the life sciences toward the fundamental understanding of structure-function relationships in normal and pathological mammalian tissue and the development of biological substitutes to restore, maintain, or improve functions." This term had to be adjusted to the existing fields of "biomedical engineering" (organ physiology and tissue behavior), "bioprocess engineering" (using living cells or microbial organisms to produce a biochemical product), and to the emerging technologies of "cellular engineering" (mammalian cell biology) [47].

Present reports on tissue engineering, as accumulated in this issue of the World Journal of Urology in most cases provide only an overview of recent developments of the past few decades and rarely reflect pioneering works of the earlier past. This article seeks to fill this gap with selected historical reflections.

\section{"Tissue engineering" in antiquity and fiction}

The Biblical tale of Eve being created from Adam's rib may be considered the first "report" of tissue engineering. This was a sort of hybrid cloning - the use of Adam's tissue to make a homologous human being of a different gender, mercifully performed under anesthesia, as described in Genesis 2: 21-22, in the recent Fox translation:

So YHWH, God, caused a deep slumber to fall upon the human, so that he slept, he took one of his ribs and closed up the flesh in its place.

YHWH, God, built the rib that he had taken from the human into a woman and he brought her to the human.

There is some debate as to the specific meaning of "rib," which could be understood as "side," such that the specific anatomical site is open to nuance of translation [18]. 
The idea that independent life can be created without sexual reproduction formed the basis of some of mankind's earliest myths. The Greek myths included the story of Prometheus being created as a human being from mud and that of Pygmalion's idealized statue of a woman brought to life by the goddess Aphrodite.

The transfer of medieval alchemy into the field of medicine produced the science of iatrochemistry. One of its most important protagonists, as the Middle Ages gave way to the Renaissance, was Theophrastus von Hohenheim, known as Paracelsus (1493-1541). His recipe for the creation of human life by mixing chemical substances (although never fulfilled) was later immortalized in literature by Johann Wolfgang von Goethe (1749-1832). In the laboratory scene of Faust (Part Two), the making of the "homunculus" in a phial is described as follows [19]:

Look there's a gleam! - Now hope may be fulfilled, That hundreds of ingredients, mixed, distilled -

And mixing is the secret - give us power

The stuff of human nature to compound

If in a limbeck we now seal it round

And cohobate with final care profound,

The finished work may crown this silent hour

It works! The substance stirs, is turning clearer!

The truth of my conviction presses nearer

The thing in Nature as high mystery prized,

This has our science probed beyond a doubt

What Nature by slow process organized,

That have we grasped, and crystallized it out.

Another extraordinary fictional example of such nonsexual creation of human life was Mary Shelley's 1818 book Frankenstein, about the scientist who made a living and sentient creature from reassembled and revitalized corpses.

Replacement of body parts has been one of mankind's earliest and most enduring fantasies as patients and healers have attempted to cope with the disabilities of disease and trauma. The legend of St. Cosmas and St. Damien, martyred in Syria in 278 AD, gives evidence of imaginative tissue engineering by transplantation. Prominent among the miraculous acts attributed to these twin physicians, who worked among the poor for no fee, was the replacement of a churchman's gangrenous leg with the limb of a dead black man. The clergyman fell asleep in church and the brothers appeared to him in a dream. One brother removed the diseased leg, while the other found a newly dead donor in a nearby cemetery, removed the corresponding leg and grafted it onto the patient's stump. The next morning the churchman awoke with a healthy black leg. When disbelievers opened the grave, they found one leg of the dead man missing, but a diseased and dismembered white leg alongside him. This imaginative bit of transplantation is wonderfully represented in a painting in the Prado from sixteenth century art and attributed to Fernando del Rincon (Fig. 1).

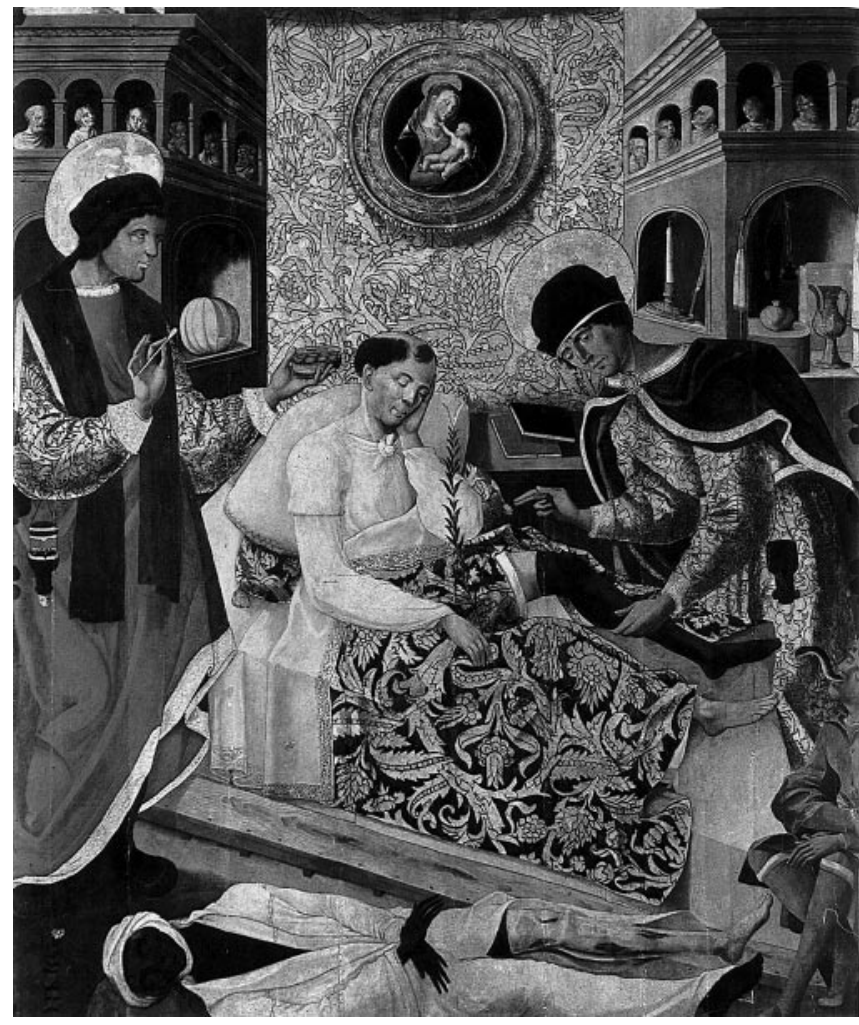

Fig. 1 St. Cosmas and St. Damian (from the Prado Museum, Madrid)

\section{Early applications of tissue substitution including transplantation of endocrine tissue}

Aside from Biblical, mythological, and fictional reports, practical applications of tissue substitution, transplantation, and regeneration began to take root. Mechanical substitution with wooden legs and dentures met common human needs. Ambroise Paré (1510-1590), the great French military surgeon, gave early descriptions of tissue engineering by replacement with prostheses in 1564, describing artificial teeth, replacement noses, and an "artificial yard" (Fig. 2) in his Dix livres de la chirurgie [49].

John Hunter (1728-1793) performed homologous transplantation of teeth in humans, a common technique in the United Kingdom during the eighteenth century ("scion-tooth"). He claimed that donor teeth should be taken from the mouth of a "sound and healthy person," and that transplanted teeth sometimes lasted for years. He also discussed the possibility of transmitting infections (lues) in some cases [25, 26]. Hunter also opened the door to transplantation of endocrine tissue [5] when he grafted testicles of cocks into the abdominal cavity of hens in 1767 . He was actually far more interested in the technique of grafting and tissue acceptance than the secondary effects on sex characteristics [27]. Adolph Berthold (1803-1861) 


\section{The defcription of a pipe, or conduit, ferving inftead of the yard in mia- king of water, which therefore wee may call as arti- ficiall $r$ ard.}

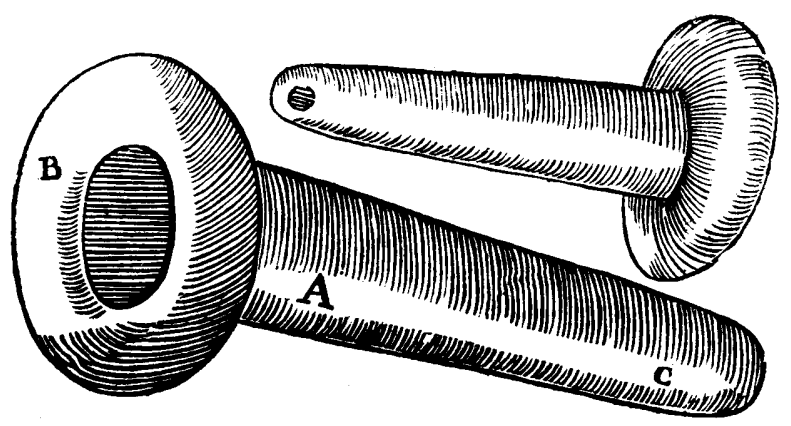

Fig. 2 Paré's artificial yard to facilitate voiding in a standing position after traumatic penile amputation. (From [49])

recognized and confirmed this humoral relationship by performing similar testicular transplantations in cockerels, first published in 1849 [6].

Later the physiologist and neurologist Charles Edouard Brown-Séquard (1817-1894) attracted attention in 1889 , at age 72 , when he self-injected a mixture of extracts from sperm, testicular tissue, and venous blood of young and vigorous dogs and guinea pigs in an attempt to revitalize himself [9]. An era of rejuvenation ensued in the 1920s [54], and one of its main protagonists in Europe was Serge Voronoff (1866-1951) who transplanted testicular tissue from ape to man in 1920 and thereafter [65]. He claimed to have treated $300 \mathrm{pa}-$ tients by applying strips of monkey testis to human recipient's testes (Fig. 3) and stated that hormonal secretion lasted for about 1-2 years, then decreased due to fibrosis of the graft. Testicular homotransplantation had been reported earlier in very few hypogonadal patients in the United States by Frank Lydston in 1914 and V.D. Lespinasse in 1915 [33, 39]. None of these was performed with vascular anastomoses.

Testosterone delivery systems are still important needs today and the Leydig cell encapsulation innovation is presented in this issue of the World Journal of Urology [40].

\section{Skin grafts: the first mainstream tissue engineering}

Skin grafts were among the earliest obvious surgical needs and offered the first practical opportunity for tissue engineering, although they created a logistic dilemma, because the grafts curled up at the edges and did not take to the recipient.

The famous surgeon Johann Friedrich Dieffenbach (1792-1847) performed tissue transplantation experiments when he was a student, and his doctoral thesis in 1822, entitled Nonnulla de Regeneratione et Transplan-

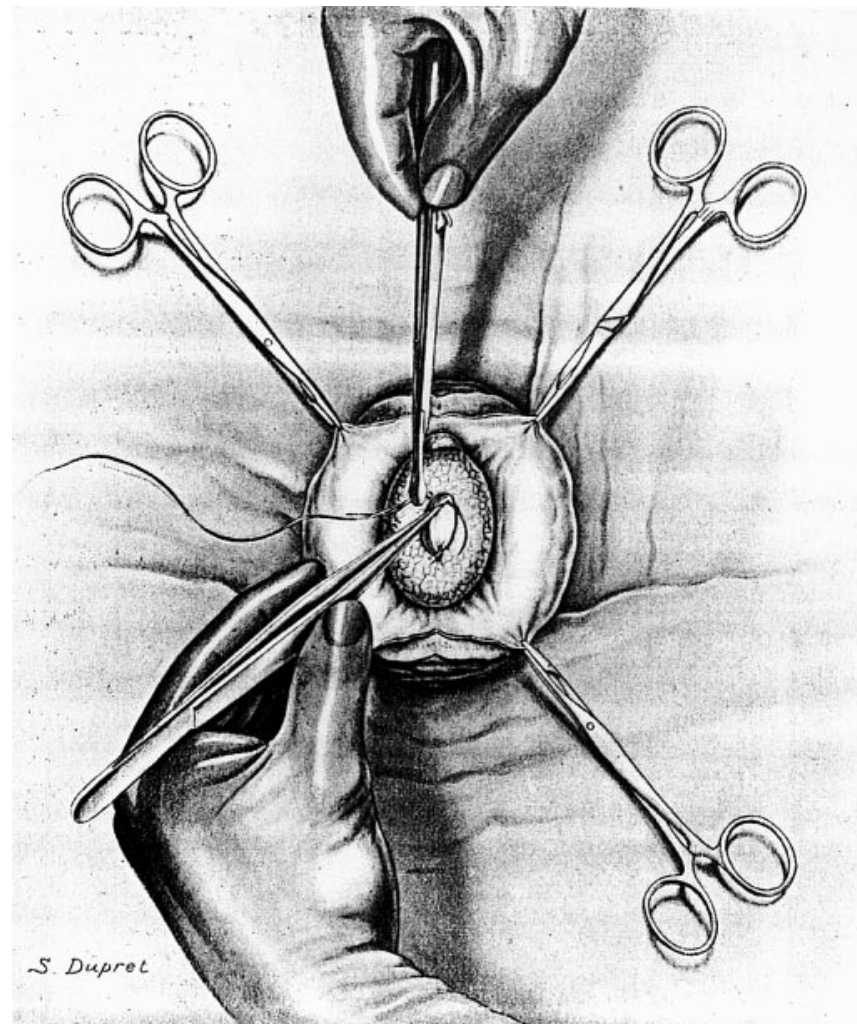

Fig. 3 Voronoff's testicular tissue transplantation from ape to man for rejuvenation. (From [65])

tatione (Fig. 4) presented his results of feather, hair, and skin transplantation in birds and mammals [16]. His subsequent efforts with free skin graft in humans failed. After 1828 Dieffenbach concentrated his efforts on use of pedicled flaps, and thus became one of the founders of modern plastic surgery [31]. A case report from Heinrich Christian Bünger details successful free autologous transplantation of skin from the thigh for rhinoplasty in 1823 and cites Giuseppe Baronio as having performed a similar procedure in 1804 [11]. In 1870 Jaques Reverdin (1842-1929) finally solved this problem of free skin grafts by placing small graft islets "the size of a split pea" on aseptic granulating surfaces. Karl Thiersch (1827-1895) went a step further, using full thickness grafts an inch square, and stabilizing them with a dressing plaster of paris. Esser (1877-1946) held even larger grafts on facial wound reconstructions by means of a sterile dental impression material, invented and sold by Dr. Charles T. Stent (see review in [7]).

Skin grafts thus became the first widely used form of tissue engineering, initially as an autotransplant and more recently as allografts and xenografts, although the latter two are largely sterile dressings for burns [51]. Autogenous skin cells have been grown in sheets in tissue culture laboratories and returned to donor patients. This must be considered modern virtuoso tissue engineering. 


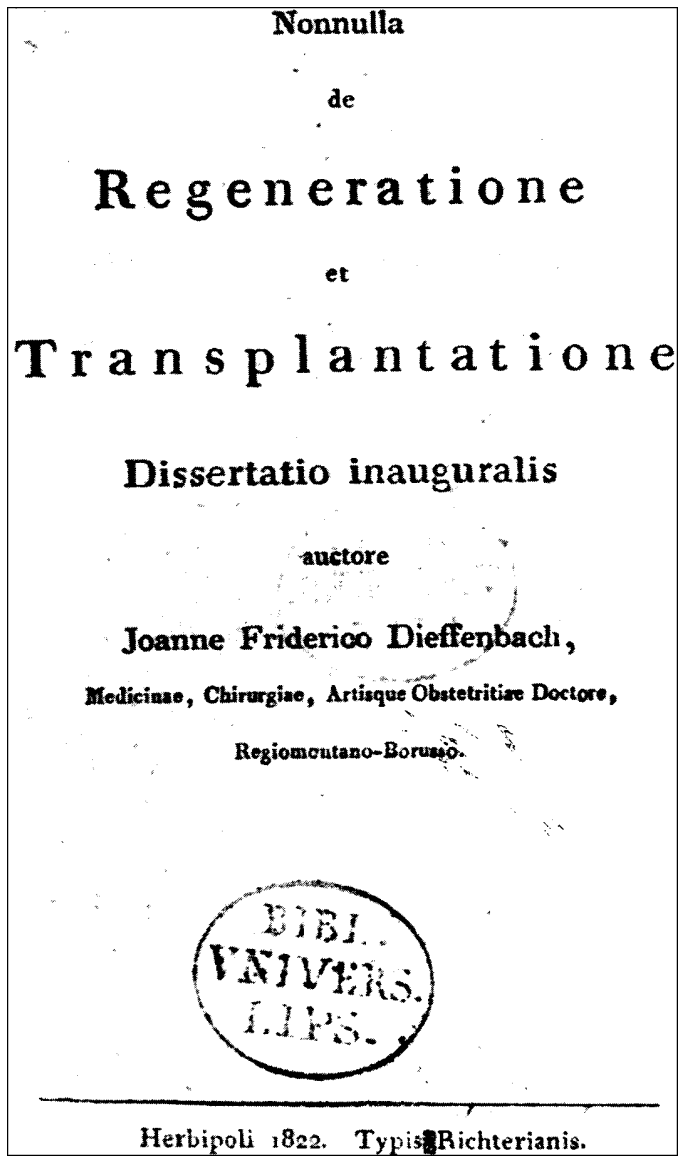

Fig. 4 Frontispiece of Dieffenbach's doctoral thesis on transplantation and regeneration from 1822. (From [16])

\section{The beginnings of cell culture technology}

Rudolf Virchow (1821-1902) established his Cellularpathologie in 1858 , confirming that tissue regeneration is dependent on cell proliferation ("omnis cellula a cellula") [64]. This led to an increased interest in histological findings, for example, of wound healing and tissue transplantation. Early studies of Karl Thiersch (1822-1895) from 1874 revealed the important interaction of granulation tissue and overgrowing epithelium for wound closure, scar retraction, and skin transplantation [58]. In $1895 \mathrm{~F}$. von Mangoldt performed autotransplantation of a matrix with cell clusters of epithelium and blood to close skin wounds. This matrix was obtained from intact skin areas of the same patient by scraping off the epithelial layer with a razor blade and transferring this mixture of tiny tissue fragments with blood onto the granulation tissue of the wound [41].

Cultivation of cells outside the body was first suggested and published by Leo Loeb in 1897, although he never documented his techniques or results [37]. Nevertheless, he did publish data on skin tissue grafts from embryo guinea pigs implanted to adult animals in 1902 [38]. C.A. Ljunggren in 1898 excised small islands of skin, kept them in ascitic fluid from one of his patients and successfully retransplanted them several days or up to 1 month later [36]. The French biologist J. Jolly, later Carrel's principal critic in France, investigated the behavior of salamander leukocytes in serum in vitro as early as 1903 [29]. According to the contemporary judgement of Carrel and Burrows in 1911, the above authors achieved "only a survival of cells outside of the body... But there was no active growth, while at the same time marked necrobiosis took place" [13].

The landmark experiment of cell culture techniques entitled "Observations on the living developing nerve fiber" was published by Ross G. Harrison (1870-1959) at the Department of Anatomy of Johns Hopkins Medical School in 1907 [21]. He cultivated the whole or fragments of the medullary tube, or ectoderm from the branchial region of frog embryos in frog lymph. After a few hours he identified sprouting of nerve fibers under the microscope, and new individual cells later emerged from that tissue. By 1910 when Harrison published a more detailed paper on his technique [22] several working groups had established cell culture laboratories. That of Alexis Carrel and Montrose T. Burrows at the Rockefeller Institute in New York became the best known [66]. Carrel assumed the role of premier tissue culture protagonist for many years. Carrel's relationship to Harrison, the myth of his chick heart cell strain that lived and multiplied for 34 years, and Carrel's influence on the development of tissue culture technology is extensively described by Witkowski $[66,67]$. Further information on the history of tissue culture after 1910 can be drawn from the work of H.B. Fell [17].

Surprisingly, the first detailed report on in vitro cultivation in urology that we could retrieve from the literature is that of benign transitional cell epithelium from R.G. Bunge in 1955 [10]. Lines of neoplastic urogenital cells were first cultivated by K.M. Richter et al. in 1957 and by R. and E. Bregman in 1961 (see review in [30]).

\section{Modern organ transplantation}

Alexis Carrel (1873-1944) was surely the chief pioneer of organ transplantation, introducing the principles of vascular anastomosis at the turn of the century [12]. The first experimental kidney transplantation in animals, performed by Emmerich Ullmann in 1902 [61], was followed by reports of unsuccessful attempts in humans by Mathieu Jaboulay in 1906 [28] and Ernst Unger in 1910 [62], who grafted animal kidneys in the elbows or groins of patients (Fig. 5). Successful whole-organ transplantation of the kidney hit the front pages of newspapers in 1954 when a team at the Peter Bent Brigham Hospital in Boston successfully moved a kidney from one identical twin to the other [44]. The report and follow-up were well documented, and the success was durable and repeatable.

Predictably, operating room innovation was far in advance of the laboratory and theoretical basis for 


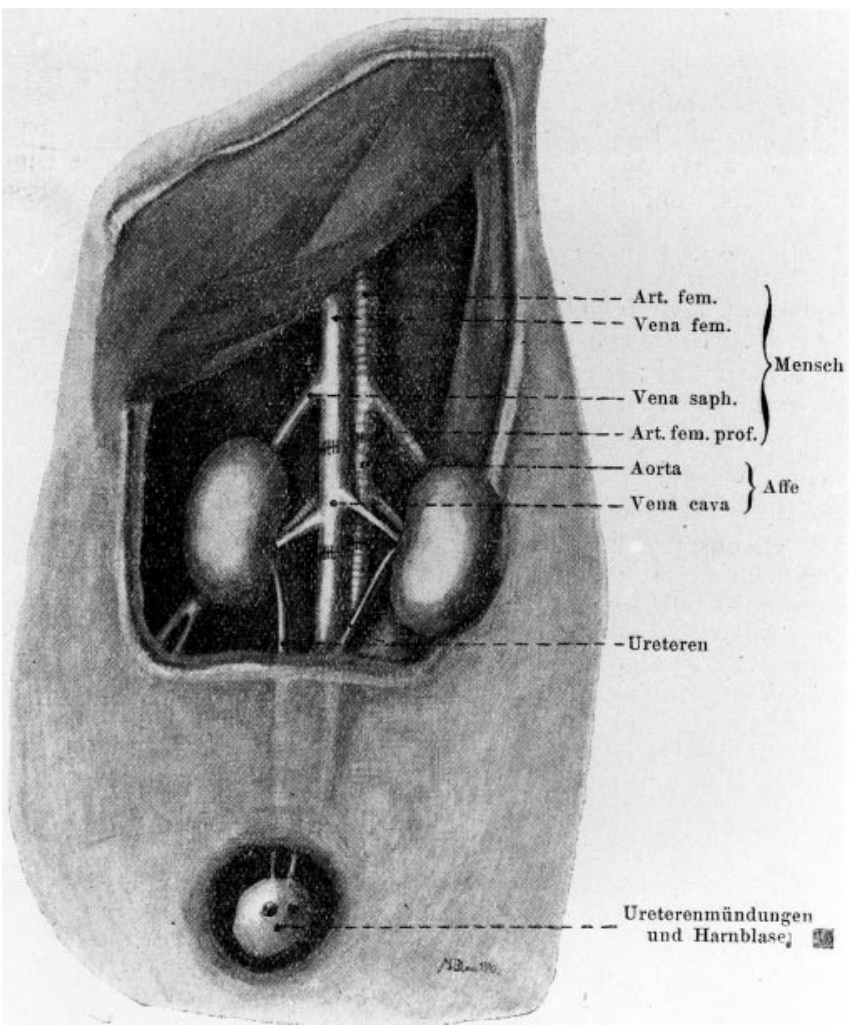

Fig. 5 Unger's first transplantation of a pair of macacus kidneys to the groin of a 21-year-old woman in 1910; the animal's opened bladder is implanted into the skin of the thigh of the patient. (From [63])

transplantation, as the art and science of immunosuppression came much later (and these are still quite imperfect). In December 1967 Christiaan Barnard at the Groote Schuur Hospital in Capetown, South Africa, performed the first successful heart transplant in human [3]. Since then livers, pancreas, small bowel, and lung have joined the list of routinely transplanted items that include skin, cornea, bone, valves, vessels, fascia, pericardium, bone marrow, and dura.

\section{Aspects of early tissue engineering in urology: urethra and bladder revisited}

Tissue engineering has had imaginative applications in genitourinary surgery, with hypospadias, epispadias, and extrophy reconstructions using local tissue and pedicled flaps in the later nineteenth century as well as novel transplantation schemes during the following century.

Free skin grafts for urethral repair were introduced by G. Nové-Josserand in 1897 [48]. J.H. Pringle described successful transplantation of a bullock's urethra to a hypospadia cripple in 1904 [50]. Alexander Tietze performed the first urethroplasty with vein in a patient with urethral stricture $6 \mathrm{~cm}$ long in 1908 [59]. As he did not succeed, probably due to the lack of postoperative urinary diversion, he gave up the method, and P. Tanton, $\mathrm{W}$. Unger and A. Becker are now credited for initiating method in 1909 [4, 57, 63]. In the same year V. Schmieden described homologous ureter for urethral replacement in hypospadias (Fig. 6) [53], and autologous mucosa of the appendix vermiformis was attempted by Erich Lexer in 1910 without success, but 1 year later with good results [34]. Stuart McGuire used normal appendix vermiformis taken from a hysterectomy patient for replacement in a boy with severe hypospadias, who happened to be the next patient on the surgical schedule one day in 1927 [42]. In 1910 F. Hohmeier closed a 4-cm urethral fistula with fascia taken from the thigh [23]. After Paul Rosenstein had used a pedicled bladder epithelial tube in 1929 [52], J. Memmelaar suggested a free graft of bladder epithelium in 1947 [43]. Although Graham Humby is generally given credit for inauguration of bucchal mucosa for urethral substitution in 1941 [24], the literature provides an earlier report in a Russian journal by I. A. Tyrmos in 1902 [60], and the method is also discussed by V. Schmieden in 1909 [53] and Erich Lexer in 1929 [35].

Many of these early reports, however, lacked rigorous follow-up and must be assigned to the realm of anecdote. More recent developments over the past few decades with free tissue grafts of tunica vaginalis, peritoneum, and rectal mucosa or various alloplastic grafts are reviewed by $\mathrm{F}$. Chen et al. [14].
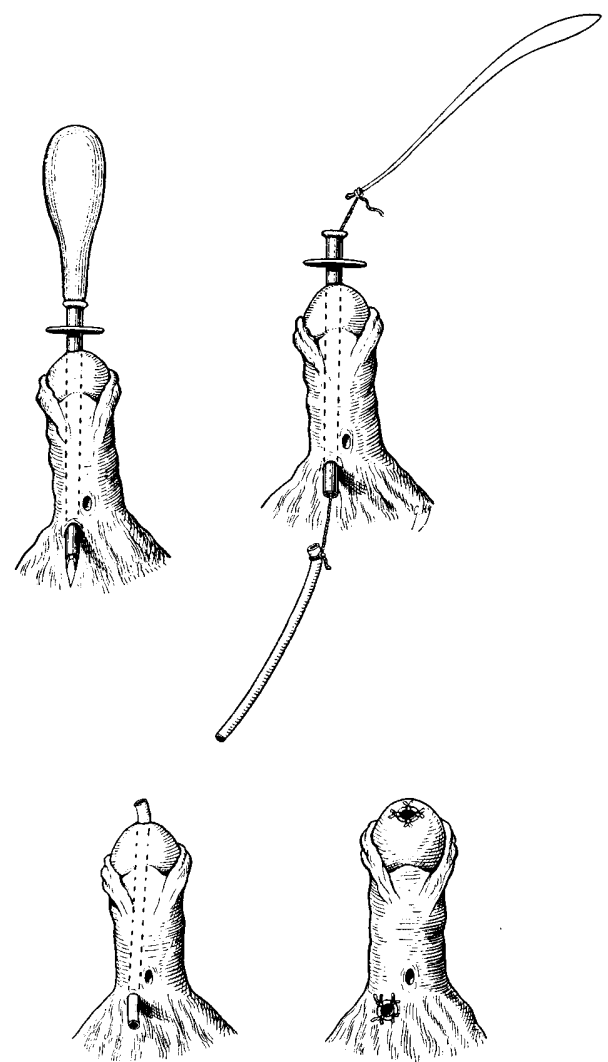

Fig. 6 Schmieden's technique of urethroplasty using homologous ureter in 1909. (From [53]) 
Tissue engineering beyond replacement or repair has reached creative heights in the urinary tract, with novel rearrangements. For a number of reasons, bladders fail to do their jobs or require excision. From first ureterointestinal diversion of John Simon in 1851 [55] to ileal conduit of Eugene M. Bricker in 1950 [8], diversions were the main solution to severe lower urinary tract dysfunction or extirpation. Substitute bowel segments, particularly those placed orthotopically, might be construed as feats of tissue engineering, but these never achieved widespread use nor were accorded substantial and durable follow-up reports until the past two decades.

Ileocystoplasty, performed experimentally in dogs at the end of the nineteenth century, and by Johann von Mikulicz-Radecki (1850-1905) in an extrophy patient in 1898 [45], seemed to work, but no large clinical experience accrued until Roger Couvelaire's five cases in Paris in 1950 [15]. After that large numbers, a total of 155, came from the separate endeavors of Cibert, Wells, Pyrah, and Gil-Vernet [46]. Willard E. Goodwin modified the approach in 1959 by opening the small bowel and reconfiguring it as a cup-patch, before anastomosis to bladder [20] - and the rest, as they say, is history [46].

Massive and imaginative reconstructions, such as those of W. Hardy Hendren in pediatric urology, going beyond bladder to involve the entire urinary, genital and lower intestinal tracts opened a golden era in surgical tissue reengineering. This was made feasible, in large part, by Jack Lapides' contribution of clean intermittent catheterization, which was the key that really unlocked the door to successful lower tract reconstruction with bowel [32]. The Mitrofanoff principle and its offshoots (such as the Yang-Monti tube) have extended the reach of bladder augmentation. Autoaugmentation, ureterocystoplasty, and composite augmentation with seromuscular patches are other new adjuncts for the reconstructionist.

Implants of biomaterials, endogenous tissue-scaffold mixes, and artificial materials are further tools on the ever expanding reconstructive workbench.

\section{Epilogue}

The future of tissue engineering holds the promise of custom-made parts, supplied by laboratory construction of tissue cultures, tissue-scaffold hybrids, organ cultures, and cloned organs. Amniocentesis additionally offers the opportunity to diagnose structural problems in utero and correct them prenatally. Perhaps the final frontier will be at the pretissue level with genetic reengineering in the zygote or even earlier. This issue of the World Journal of Urology gives a snapshot of the state-ofthe-art of tissue engineering at the start of the third millenium of the modern world.

\section{References}

1. Agnes M, Laird C (1996) Webster's New World dictionary and thesaurus. Simon \& Schuster Macmillan, New York

2. Anonymous (1995) Stedman's medical dictionary, 26th edn. Williams and Wilkins, Baltimore

3. Barnard C, Pepper CB (1969) Christiaan Barnard - one life Timmins, Cape Town

4. Becker A (1909) Eine neue plastische Operation bei hochgradiger Hypospadie. Zentralbl Chir 36: 102

5. Benedum $\mathbf{J}$ (1999) The early history of endocrine cell transplantation. J Mol Med 77: 30

6. Berthold AA (1849) Über die Transplantation der Hoden. Arch Anat Physiol Wissensch Med 16: 42

7. Bloom DA, Clayman RV, McDougal E (1999) Stents and related terms: a brief history. Urology 54: 767

8. Bricker EM (1950) Bladder substitution after pelvic evisceration. Surg Clin North Am 30: 1511

9. Brown-Séquard CE (1889) The effects produced on man by subcutaneous injection of a liquid from the testicles of animals. Lancet 137: 105

10. Bunge RG (1955) Cyto-dynamic properties of urinary neoplasms. V. cultivation in vitro of transitional cell epithelium. J Urol 73: 101

11. Bünger HC (1823) Gelungener Versuch einer Nasenbildung aus einem völligen getrennten Hautstück aus dem Beine. J Chir Augenhkd 4: 569

12. Carrel A (1902) La technique opératoire des anastomoses vasculaire et la transplantation des viscères. Lyon Med 98: 859

13. Carrel A, Burrows MT (1911) Cultivation of tissues in vitro and its technique. J Exp Med 13: 387

14. Chen F, Yoo JJ, Atala A (2000) Experimental and clinical experience using tissue regeneration for urethral reconstruction. World J Urol 18: 67

15. Couvelaire R (1950) La 'petite vessie' des tuberculeux génitourinaires. Essai de classification place et variantes des cystointestino-plasties. J Urol Med Chir 56: 381

16. Dieffenbach JF (1822) Nonnulla de Regeneratione et Transplantatione. Richter, Würzburg

17. Fell HB (1972) Tissue culture and it's contribution to biology and medicine. J Exp Biol 57: 1

18. Fox E (1983) The Schoken Bible, vol 1. Schoken, New York

19. Goethe JW (1831/1959) Faust (part two) Act I: Laboratory Penguin, Harmondsworth

20. Goodwin WE, Winter CC, Barker WF (1959) Cup patch technique of ileoaptoplastic for bladder enlargement or partial substitution. Surg Gynecol Obstet 108: 240

21. Harrison RG (1907) Observations on the living developing nerve fiber. Proc Soc Exp Biol N Y 4: 140

22. Harrison RG (1910) The outgrowth of the nerve fiber as a mode of protoplasmic extension. J Exp Zool 9: 787

23. Hohmeier F (1911) Ueberbrückung eines ausgedehnten Harnröhrendefektes durch freie Faszien-Plastik. Dtsch Med Wochenschr 19: 887

24. Humby G (1941) A one-stage operation for hypospadias. Br J Surg 29: 84

25. Hunter $\mathbf{J}$ (1771) The natural history of the human teeth. Johnson, London

26. Hunter $\mathbf{J}$ (1788) A treatise on the venereal disease. London

27. Hunter J (1835-1837) The works of John Hunter, vols 1-4. Palmer JF (ed). London

28. Jaboulay M (1906) Greffe de reins au pli du coude par soudures artérielles et veineuses. Lyon Med 107: 575

29. Jolly J (1903) Sur la durée de la vie et de la multiplication des cellules animales en dehors de l'organisme. Compt Rend Soc Biol Paris 55: 1266

30. Jones GW (1967) Primary and metastatic epithelial tumors of the human kidney and bladder in tissue culture. Cancer 20: 1893

31. Lampe R (1934) Dieffenbach. Barth, Leipzig 
32. Lapides J, Diokno AC, Lowe BS, Kalish MD (1974) Followup on unsterile, intermittent self-catheterization. J Urol 111: 184

33. Lespinasse VD (1914) Transplantation of the testicle. Chic Med Rec 36: 402

34. Lexer E (1911) Der Ersatz eines Harnröhrendefektes durch den Wurmfortsatz Med Klinik 39: 1491

35. Lexer E (1929) Zur Operation der Hypospadie. Zentralbl Chir 56: 464

36. Ljunggren CA (1898) Von der Fähigkeit des Hautepithels, ausserhalb des Organismus sein Leben zu behalten, mit Berücksichtigung der Transplantation. Dtsch Z Chir 47: 608

37. Loeb L (1897) Ueber die Entstehung von Bindegewebe, Leukocyten und roten Blutkörperchen aus Epithel und über eine Methode, isolierte Gewebsteile zu züchten. Stern, Chicago

38. Loeb L (1903) Ueber das Wachsthum des Epithels. Roux Arch Entwicklungsmechanik Org 13: 487

39. Lydston GF (1915) Sex gland implantation: some further experimental observations. N Y Med J 51: 601

40. Machluf M, Orsola A, Atala A (2000) Controlled release of therapeutic agents: slow delivery and cell encapsulation. World J Urol 18: 80

41. Mangoldt F (1895) Die Ueberhäutung von Wundflächen und Wundhöhlen durch Epithelaussaat, eine neue Methode der Transplantation. Dtsch Med Wochenschr 21: 798

42. McGuire S (1927) Use of appendix vermiformis in the formation of a urethra in hypospadia. Ann Surg 85: 391

43. Memmelaar J (1947) Use of bladder mucosa in a one-stage repair of hypospadias. J Urol 58: 68

44. Merrill JP, Murray JE, Harrison JH (1956) Successful homotransplantation of human kidney between identical twins. JAMA 160: 277

45. Mikulicz-Radecki J (1899) Zur Operation der angeborenen Blasenspalte. Zentralbl Chir 26: 641

46. Murphy LJT (1972) The history of urology. Thomas, Springfield

47. Nerem RM (1991) Cellular engineering. Ann Biomed Eng 19: 529

48. Nové-Josserand G (1897) Traitement de l'hypospadias: nouvelle méthode. Lyon Med 85: 198

49. Paré A (1634) The works of that famous chirurgion Ambrose Parey. Cotes and Young, London
50. Pringle JH (1904) Repair of the urethra by transplantation of the urethra of animals. Ann Surg 40: 387

51. Pruitt BA Jr (1997) The evolutionary development of biologic dressings and skin substitutes. J Burn Care Rehabil 18: S2

52. Rosenstein P (1929) Ersatz der fehlenden Harnröhre bei der Hypospadia penoscrotalis durch Blasenschleimhaut. Z Urol 23: 627

53. Schmieden V (1909) Eine neue Methode zur Operation der männlichen Hypospadie: freie Transplantation des Ureters zum Ersatz der Urethra. Arch Klin Chir 90: 748

54. Schultheiss D, Denil J, Jonas U (1997) Rejuvenation in the early 20th century. Andrologia 29: 351

55. Simon J (1852) Ectropia vesicae: operation for diverting the orifices of the ureters into the rectum. Lancet 2: 568

56. Skalak R, Fox CF (ed) (1988) Tissue engineering. Liss, New York

57. Tanton P (1909) La transplantation veineuse par l'autoplastie de l'urétre. Presse Med 17: 65

58. Thiersch K (1874) Ueber die feineren anatomischen Veränderungen beim Aufheilen von Haut auf Granulationen. Arch Klin Chir 37: 323

59. Tietze A (1909) Ueber Versuche zur Transplantation lebender Gefässstücke auf andere Hohlorgane des Körpers. Berl Klin Wochenschr 8: 333

60. Tyrmos IA (1902) About treatment of urethral defects by transplantation of mucosa (in Russian). Russkiy Chiruryicheskiy Archiv (Russian Surgical Archive) 5: 1036

61. Ullmann E (1902) Experimentelle Nierentransplantation. Wien Klin Wochenschr 15: 281

62. Unger E (1910) Nierentransplantationen. Klin Wochenschr 1: 575

63. Unger W (1909) Discussion on Becker's paper. Zentralbl Chir 36: 104

64. Virchow R (1858) Die Cellularpathologie in ihrer Begründung auf physiologische und pathologische Gewebelehre. Hirschwald, Berlin

65. Voronoff S (1925) Rejuvenation by grafting. Allan \& Unwin, London

66. Witkowski JA (1979) Alexis Carrel and the mysticism of tissue culture. Med Hist 23: 279

67. Witkowski JA (1980) Dr. Carrel's immortal cells. Med Hist 24: 129

\section{EDITORIAL NOTE}

Due to an unfortunate mistake we did not mention Wade Bushman as editor of World Journal of Urology volume 17, issue no. 6, "Urinary tract infection". We regret this oversight. Please accept our sincere apologies for any inconvenience caused. 